\title{
EDUCATIONAL WORK WITH GIFTED CHILDREN THROUGH INTERNET IN CHINA (ON THE EXAMPLE OF COMMUNICATIVELY GIFTED CHILDREN)
}

\author{
Wu Yanlin \\ H.S. Skovoroda Kharkiv National pedagogical University, Ukraine \\ Ruslan Chornovol-Tkachenko \\ H.S. Skovoroda Kharkiv National pedagogical University, Ukraine
}

\begin{abstract}
Chinese pedagogical science always had rather complex relationship with the concept of «giftedness» as a social and educational reality because only the person's social success (good position, social and professional demand, maximum compliance with the social ideal of society) was seen as the sign of the person's giftedness in traditional Chinese pedagogy. Online education always considered to be a supporting form of education service in China or a variant of education service providing for special categories of children (hard-to-reach children, children with special physical and educational needs, those who are in difficult life situations: imprisoned, in hospital etc). However the 2020 pandemic situation faced the whole world and China in particular with the need to reconsider views as to the place of distance education. All pedagogical and educational work in the world has been moved online and work with gifted children is of no exception. The article aims to present the Chinese experience of online work with gifted children (especially the communicatively gifted ones) by the means of special education platforms and programs. To write the article, a complex of theoretical and empirical research methods was used (abstraction method, analysis of pedagogical literature, induction and deduction, observation etc.).
\end{abstract}

Keywords: communicatively gifted children; creative education; distance education; education platform; gifted children; online education; socially gifted.

\section{Introduction}

Revealing, development and support of gifted children, ensuring their personal, social self-realization and professional self-determination is a modern social order, which determines "the preservation of the country's national gene pool, the formation of the future highly professional elite in various fields of intellectual and creative activity" (Clark, 2008). The issue of children's giftedness, educational work with them, development of their abilities refers, on the one hand, to the rather studied ones, on the other hand, it is a subject of ongoing disputes in the pedagogical environment. By the beginning of the XXI 
Yanlin \& Chornovol-Tkachenko, 2021. Educational Work With Gifted Children Through Internet In China (on the Example of Communicatively Gifted Children)

century the problem of identifying and developing of gifted children, realizing their potential has not lost its relevance, but scientific views on what constitutes children's giftedness, what are its types, methods of identification, pedagogical methods of development, have changed in many ways. New types of giftedness were identified (empathic, leadership, social, communicative, etc.).

The giftedness of children became the subject of the Chinese pedagogical sciences`attention only in the second half of the XX century. Then appeared the system for the selection of children gifted in various fields of activity (science, music, sports, technology) with their further relocation to specialized educational institutions (mainly of the boarding type) for the maximum development of their abilities. Communicatively gifted children present a special category of gifted children as the processes of working with such children goes systematically in the process of obtaining general education and do not imply the exclusion of communicatively gifted children from the primary children's collective for subsequent transfer to specialized internats or classes. The Chinese education system is interested in the early identification and development of such children, since it is them who are subsequently considered as the personnel reserve of the Party and social movements in the country.

Computer technologies today are an integral part of the education systems around the world. Thanks to the good financial support from the state, China today can be considered the flagship in the use of computer programs and the Internet in the educational process. However, the majority of modern computer products, cracking for the development of a certain type of giftedness, bypass the work in the field of communicative giftedness.

In the research we used a complex of pedagogical methods traditional for research of such kind: analysis of pedagogical literature, media materials, documentation on issues of both distance educational work with children in general and the practice of working with communicatively gifted children in particular in the Peoples Republic of China (PR China) and abroad; praximic methods (process analyses of practical activities in this area of education; method of independent characteristics); analysis and synthesis of existing approaches and theoretical ideas; induction and deduction; classification; analogy; comparison; hypothesis making; forecasting. Among the empirical methods that were used while making the research, there can be named observation, pedagogical consulting, studying, generalization and dissemination of typical and advanced pedagogical experience of the PR China in the field of requirements for modern educational IT product. 


\section{Literature Review}

Since the subject of this article is complex and consists of at least 3 components (the general concept of communicative giftedness, the features of educational work with gifted children in the context of online education and the features of IT product for gifted children's activities in modern China), the characteristics of modern scientific research will also consist of 3 blocks. We have not found studies that would raise the issue of pedagogical work with communicatively gifted children in the context of online education, in particular in the PR China.

Based on the most popular interpretations of the giftedness concept (which came to education from psychology), modern world and Chinese pedagogy see giftedness as:

- qualitatively unique combination of abilities that ensures successful performance of the activity (J. Renzulli and others) (Renzulli, 2016);

- general ability that determines the breadth of a person's capabilities, conditions and originality of his activities (Abraham, 2018);

- mental potential, or intellect; a holistic characteristic of (individual) cognitive and learning abilities (S. Schroth, J. Helfer and others) (Schroth \& Heifer, 2019);

- $\quad$ talent, the presence of internal conditions for outstanding achievements and activities (Liu \& Barnhart, 2006);

- a high level of development of any abilities (scientific, artistic, creative etc.) (R. Sternberg \& K. Sternberg, 2016);

- dominance of a certain trait of a person's character, which determines his /her personality type, behavior, etc. (empathic giftedness, social giftedness, communicative giftedness etc.) (Chenneville \& SchwatrzMette, 2020).

Most modern scientific works by both Chinese and foreign researchers devoted to the issues of pedagogical work with gifted children in China and the PR China today are mainly devoted to the issues of gifted children selection and training system `s genesis in China with the emphasis on the historical component (Zhang, 2018); comparison of the Chinese and American, British and Russian systems of work with this category of children (Dai, Steenbergen-Hu, \& Yang, 2016) and the innovations that the Chinese educational institutions of the informal education use in the practice of working with gifted children (Liu \& Barnhart, 2006).

Such researchers as R. Liu (Liu \& Barnhart, 2006), X. Zhao (2020) in their publications raise questions about the use of modern IT technologies in education in the PR China, insisting on the point of view that these programs should be a 
Yanlin \& Chornovol-Tkachenko, 2021. Educational Work With Gifted Children Through Internet In China (on the Example of Communicatively Gifted Children)

common product of computer and educational specialists, as well as putting forward a number of requirements for an IT product that can be used for the education sector and what components should be present, if a particular program is positioned as the one to be used in work with gifted children

\section{Results}

Understanding of talentness and giftedness at all times was far from ambiguous. The idea of giftedness is influenced by cultural and historical conditions: social structure, social values, social ideology, social stereotypes, as well as scientific views and concepts in a particular country in a particular time. Every society defines giftedness according to its needs, therefore its understanding changes depending on time and place. Various types of human activity require different types of giftedness, types of personal orientation. According to the types of activity and the spheres of the psyche that provide it, the following types of talent are traditionally distinguished:

- General intellectual (encyclopaedic);

- Academic (mathematical);

- Creative;

- $\quad$ Artistic and aesthetic;

- Communicative;

- Psychomotor;

- Practical;

- $\quad$ Spiritual and value (Piechowsky, 2019).

The characteristics and needs of different groups of talented children and youth vary greatly, they need different support programs, the system of events that would be closely related to the main type of the talent the child has.

The communicative abilities of a person occupy an important place in the general structure of human abilities. The level of their development determines how successfully the individual can communicate with others. Communication is one of the key factors in development and socialization of a person; without it, these processes are impossible. Through communication a person assimilates information, knowledge, experience, norms, etc., and also identifies himself/herself as a person.

As modern studies show (Rogers, 2002), success in life is often achieved not by those who have highly developed intellectual abilities, but by the people who can easily enter into communication, establish favorable interpersonal relationships. The basis of success in a social environment largely depends on communicative abilities and giftedness. Communicative giftedness covers a wide area of social relations at the "person - person" level, presupposes the innate 
ability of a person to establish contacts, to understand human behavior correctly, to express judgments about people quickly and accurately, to understand and predict the behavior of another person and to build high-quality interpersonal relationships. Communicatively gifted people are characterized by a high level of intelligence, well-developed intuition, understanding of feelings and needs of other people, ability to empathize, a vivid sense of humor that helps them to get in touch with other people and to be liked by them (Smith, 2015). Communicative giftedness is an integral part of leadership as a personal characteristic of a person, which is the subject of special attention for the system of pedagogical work with a child in China.

There are many prerequisites for the development of communicative giftedness during childhood. At this time, self-awareness, the need for communication with adults and peers, the ability to empathize, empathy is actively formed, social emotions and feelings develop. Communicatively gifted children are always leaders in a children's team. They have early leadership qualities that contribute to the unification of the children's microcollective. They are distinguished by their activity, a seen interest in people, and the need for communication. It is precisely the communicatively gifted children who become the initiators of interaction in any group. A communicatively gifted child often takes on the role of organizer of collective games and other group activities. Possessing good speech skills, he/she can tell the teacher or other grown-ups what other children want, as a lot of children find it difficult to express their thoughts. In other words, communicatively gifted children are not afraid of grown-ups at any age, they see them as interlocutors and communication partners. Such children always show a willingness to help their peers with advice or deed, they are able to settle emerging conflicts (Bar-On, 2007). Most of children want to communicate and be friends with communicatively gifted children.

Communicatively gifted children clearly imagine how any game or activity can be organized, they know how to create conditions for games or activity: they choose a place, assign roles, find the necessary toys and tools, determine the content of the game or activity and always bring something new into it (mainly into the procedure or predicted result). Such children participate with interest in conversations on the topic of the upcoming game or activity, ask adults many questions in order to learn something new and are happy to share their impressions with everyone around them. Vivid impressions allow communicatively gifted children to take a more responsible attitude to everything they do. They are inventive in their actions with toys, imitate their voices and conduct conversations with them, their activities are emotional in nature. More often communicatively gifted children willingly take on the main roles and do well with them. They often 
Yanlin \& Chornovol-Tkachenko, 2021. Educational Work With Gifted Children Through Internet In China (on the Example of Communicatively Gifted Children)

show exaggerated demands on their peers, striving for leadership (Smith, 2015; Sternberg, 2015).

The preschool group is the first children's community in which communication and various types of children's activities are formed and developed, a new social role is acquired - a member of a children's group, relationships with peers are formed. The task of the preschool and school education system in the PRC is to identify and monitor communicatively gifted children. In contrast to many Western countries (Israel, Ukraine, France, etc.) where the term "hyperactive" is often used for communicative (socially) gifted children and it is believed that this aspect requires pedagogical (and sometimes medical) correction, in modern China, even in kindergarten, such children become "assistants" of the educator and the development of their communicative giftedness goes on systematically and naturally. The kindergarten charter stipulates that each teacher must have at least 2 assistants from among the children of the group. It is believed that this stimulates the children of the group to selforganization, teaches children to be vertical in the team, etc. In cases when there is no informal leader in the group (a child with a seen communicative giftedness), the teacher must observe the children and, during the first 15 days of their stay in kindergarten, identify children with potential leadership qualities and signs of communicative talent. This type of activity is very important for the education system in the PRC today. Communicatively gifted children, passing from nursery school to elementary one and from elementary school to middle school, receive a special mark in the student's personal card and have bonuses for admission to a pioneer or young communist party organizations, become leaders of social movements and subsequently can make a wonderful career in the spheres of public activity or management (Dai, Steenbergen-Hu, \& Yang, 2016).

There is one more thing that should be mentioned while analysing the problem of communicative giftedness of children. The main peculiarity of sensual types of giftedness (which includes communicative) is that it does not imply the process of selecting children for special classes or developing and improving of their giftedness in artificially created additional educational institutions (which include children's clubs, individual and group lessons, etc.). The usual mechanisms traditionally used with other types of giftedness (individual work, specialized clubs and courses mainly in non-formal education) do not work with communicatively gifted children, since they need an audience and the realization of their own leadership ambitions for development (Zhao, 2020).

The Coronavirus pandemic turned up to be a real challenge for without the exception every well-established social schemes and models for organizing life and human activities. On the one hand, protracted quarantine and self-isolation as a social phenomenon showed the vulnerability of existing medicine, economics, 
public administration and education as existing systems. However, on the other hand, the need to continue life and work, even in such conditions, led to a sharp appearance or activation of forms that before the Corona were only under development. Currently, there are many programs of artificial intelligence (AI) that help in education, thanks to which students, schoolchildren and teachers get huge benefits. The use of artificial intelligence capabilities in teaching humanitarian disciplines or humanities is today the subject of discussion among methodologists. Today in the pedagogical space there are many programs and methods of teaching various disciplines for students of different ages who use the capabilities of artificial intelligence. However, these programs mainly exist in the field of non-formal education or for individual use to increase the level of knowledge.

However, if online learning and educating techniques are very effective for the development (self-development, improvement) of abilities and those types of giftedness that are associated with knowledge (mathematics, physics, technology, languages, etc.), sufficiently applicable and justified for creative types of giftedness (literary, artistic, musical, etc.), as "sensory" giftedness (empathic, communicative) computer platforms and programs are useless. This fact can be explained as the developers of today's IT products deliberately do not take into account (or technically cannot satisfy) the communicative component, which gives live communication and education in a classroom. The following factors are not taken into account:

1. the child's need for communication;

2. the child's need to form and organise the circle and rules of communication according to his own understanding;

3. the need for leadership and demonstration of their communication skills with the support of adults;

4. a communicatively gifted child needs "time to think" before giving out a result, an answer, etc .;

5. The child gets very upset if the process that he builds on his own, and its predicted result differs from the "ideal" (which is proposed by the program) (Zhang, 2018; Liu \& Barnhart, 2006).

However, defining communicative giftedness as a social and educational value, the Chinese education system, even in the conditions of complete online education, managed to maintain an attitude towards the preservation and development of communication skills in children and youth. To resolve this problem in the PR China online education process the following ways were used:

1. A complex of educational IT products that involve the creation of groups of students, self-structuring of such groups, their communication in the virtual space to complete homework and other educational tasks. Such activities being 
Yanlin \& Chornovol-Tkachenko, 2021. Educational Work With Gifted Children Through Internet In China (on the Example of Communicatively Gifted Children)

mandatory allow to satisfy the need of communicatively gifted children in organizing their own and the group`s communication, the need for leadership, in the distribution of roles in the group, etc. Also, this type of activity contributes to the development of linguistic and managerial abilities of communicatively gifted children (Delisle, 1992). Also as certain "know-how" can be considered the grading system in such tasks: the grade is not given to the group as a whole, but a certain number of points should be distributed among all members of the group, depending on the quantity and quality of the work made by the particular member of the group to complete the homework. In upper classes of secondary school and high school programs, the authority to allocate points among the group members belongs to the group leader with the obligatory explanation of his/her point of view. Since all assessment sheets in such programs are usually free to be seen and imply access to them by both the teacher and the rest of the group, this type of activity is quite correlated with such features of communicatively gifted children as responsibility (hyperresponsibility) and leadership as well as neutralizes the factor of personal relationship of the group leader when assessing, fosters in the child a sense of justice and responsibility for their actions.

2. It is generally accepted (Prather, 2018) that the family is the main factor in the development of communicative giftedness at an early age. A favorable atmosphere in the family, trusting relationships with parents and other family members affect the formation of a child's social interest. Communicative giftedness is formed in children in families with a democratic style of adult communication with each other and with children, where personal communication and joint pastime are valued. Children are given the opportunity for independent actions and decisions, but there is also a certain reasonable control over their actions. A number of tasks that are offered today to the Chinese children and schoolchildren (especially in primary school) are aimed at the joint work of parents and children. Many tasks begin with the words: "Ask your parents...», "Find out from older family members...», "Do it with your parents...». A popular type of hometasks is intra-family polls and questionnaires on some specific questions. The child must not only independently create a questionnaire, but also choose the right place, time, form of communication in order to interview parents and other family members (aunts, uncles, older relatives). The Chinese are usually very responsible about the education of children and the tasks given by teachers are seen as an unjustified axiom. Therefore, many relatives usually take part in making these types of school home tasks (using social networks, WeChat significantly facilitate the process of hometask making). These types of tasks teach and activate children's ability to communicate with different age groups, build relationships with them, organize their own time for communication and take into account the situation of other 
people and their desire / unwillingness to communicate on a certain topic "here and now." All these actions meet the needs of communicatively gifted children.

3. With the beginning of massive compulsory online education, schools in the PR China received unprecedented financial and technical assistance from the country. This money and opportunities were aimed and spent not only at improving the material and technical situation in educational institutions of the country, but, to a greater extent, at providing the educational process itself. In order to preserve (or preserve as much as possible) all the functions of the educational process, including the communicative one, at the state level support services for the educational process was created. To make it functional and really working, there were involved a large number of technical personnel (computer professionals) and young teachers (who study at the latter course of pedagogical higher and professional educational institutions and those who are undergoing a teaching internship). On average, today, besides the teacher him/herself, 4-6 people take part in the lesson. The work of the technical support specialists, who accompany a lesson, consists in the selection of technical means and technical support of the lesson itself (including such an element as group-working). The task of the junior pedagogical staff (teacher assistants) is «to ensure and stimulate the process of communication between all participants of the educational process, taking into account their individual and personal characteristics» (Smith, 2015). In other words, thanks to high-quality technical support and the involvement of a large number of people into the educational process, in the PR China the educational process was mechanically transferred to the online space with the maximum preservation of all functions of the offline educational one.

It can be said that today the PR China uses the most advanced methods of working with communicatively gifted children, as it sees in them the potential that meets the social order of the Chinese society and the Party for socially active, attractive people who know how to lead, manage and lead the nation.

\section{Conclusions}

Today everything that goes on in China is of particular interest for the rest of the world not only because the country in a short period of time (about just a century) has made a great breakthrough in all spheres of life (science and technology, economics, culture and sports, education, and so on), but also because the country presents to the world non-trivial ways of solving problems (including the educational ones), which are invariably distinguished by high efficiency and healthy pragmatism. China is a country that has rapidly approached the socioeconomic level of the world's leading nations. This phenomenon can be explained by the high level of specialists` training in all spheres of public life as well as by 
Yanlin \& Chornovol-Tkachenko, 2021. Educational Work With Gifted Children Through Internet In China (on the Example of Communicatively Gifted Children)

rational use of human potential. That is why the question of a detailed study of the Chinese system of work with gifted children, in particular with communicatively gifted ones, to stimulate the development of children's talents in the Chinese state is quite relevant. Communicatively gifted children, as it was repeatedly noted in the article, are seen as a personnel reserve of party and public organizations, social movements in the country. The planned and natural development of communicative giftedness is the part of modern education system`s tasks in China. The transition of the education system to the online format set the task for the Chinese teachers to preserve all the functions and tasks of the education system (including the identification and development of communicative giftedness in children). In this regard, appeared a complex of methods that correspond to the current technical, material and pedagogical capabilities of the country at the present time, and the product of its implementation meets the social and state demand for the education system as much as possible.

\section{References}

Abraham, A. (2018). The neuroscience of creativity. Cambridge University Press.

Bar-On, R. (2007). The impact of emotional intelligence on giftedness. Gifted Education International, 22(1), 122-137. DOI: 10.1177/026142940702300203

Chenneville, T. \& Scwartz-Mette, R. (2020). Ethical considerations for psychologists in the time of COVID-19. American Psychologist, 5 (21). DOI: 10.1037/amp0000661

Clark, B. (2008). Growing up gifted. Upper Saddle River, NJ: Pearson Prentice Hall.

Dai, D. Y., Steenbergen-Hu, S., \& Yang, Y. (2016). Gifted education in Mainland China: How it serves a national interest and where it falls short. Gifted education in Asia: Problems and prospects. Charlotte, NC: Information Age Publishing, 51-76.

Delisle, J. (1992). Guiding the Social and Emotional Development of Gifted Youth. New York: Longman Publishing Group.

Liu, J., Barnhart, R. (2006). Chinese gifted teenage university program. The Journal of Special Education, 30, 204-212. DOI: https://doi.org/10.1177/002246699603000205

Piechowsky, M. (2019). The inner world of the young and bright. Psychology, 38, 5-67, 156157. Retrieved from: https://www.positivedisintegration.com/Piechowski2009b.pdf

Prather, K. (2018). Why Socially Gifted was formed: a parent perspective. https://www.sociallygifted.org/resource/5/Why-Socially-Gifted-was-formed-a-parentperspective/article

Renzulli, J. (2016). Reexamining the role of gifted children education and talent development for the 21st century: a four-part theoretical approach. International Journal for Talent Development \& Creativity, 141, 23-51. DOI: 10.1177/0016986212444901

Rogers, K. (2002). Re-forming Gifted Education: How Parents and Teachers Can Match the Program to the Child. Scottsdale, AZ: Great Potential Press.

Schroth, S. \& Heifer, J. (2019). Parenting gifted children to support optimal development. National Association for Gifted children. Retrieved from: 
https://www.nagc.org/sites/default/files/WebinarPowerPoints/Parenting\%20Gifted\%20 Children\%20to\%20Support\%20Optimal\%20Development.pdf

Smith, D. (2015). Social giftedness: Its characteristics and identification. Gifted Education International, 11 (1), 24-30.

Sternberg, R. (2015). WICS: A model of giftedness in leadership. Roeper Review, 29,103-127. DOI: https://doi.org/10.1080/02783190509554335

Sternberg, R. \& Sternberg, K. (2016). Cognitive psychology. Nelson education.

Zhang, Zh. (2018). Gifted education in China. Cogent education. https://www.tandfonline.com/doi/full/10.1080/2331186X.2017.1364881

Zhao, X. (2020). Reflections of a gifted program in China. Gifted and Talented International, $11,80-83$. 